\title{
Effects of Cattle and Deer on Regenerating Mixed Conifer Clearcuts
}

\author{
BARBARA H. KOSCO AND JAMES W. BARTOLOME
}

\begin{abstract}
Study began in 1977 at Blodgett Forest Research Station near Georgetown, California, to look at the effects of cattle and deer grazing on mixed conifer plantations. Cattle graze the study area from June 1 until about September 20 each year. Deer are primarily migratory, passing through the study area in March and April and again in October and November each year. The results of treatments on two clearcuts indicate cattle do not harm tree regeneration. Browsing on trees occurred, but no significantly higher numbers of trees were browsed by cattle and deer than by deer alone. White fir seedlings were browsed the most heavily. No trampling damage occurred. Browsing has made no difference in overall tree seedling height or basal diameter between treatments. Brush cover was significantly reduced on grazed treatments on both clearcuts. On $641 \mathrm{E}$, cattle and deer grazing together made a further significant reduction in brush cover over deer grazing alone. The reduction in brush cover has had no effect on tree seedling heights or basal diameters yet. Tree height, basal diameter, and browsing and trampling damage will continue to be monitored, as will brush cover and species composition. Results from this study indicate however, that proper cattle grazing does not harm tree regeneration on young mixed conifer plantations and furthermore cattle grazing may be used as a vegetation management tool in reducing brush on these clearcuts.
\end{abstract}

Damage to conifer tree seedlings from browsing animals often limits successful tree regeneration. In California, much of the damage to tree regeneration is done by big game. Deer damage has been reported in every forested part of the state (Schubert and Adams 1975). The degree of damage often depends on the amount of other forage available (Roy 1960) because deer tend to browse trees when other forage is scarce. Clearcutting or selective harvesting systems open up the forest. Increased understory plant diversity provides favorable habitat for deer. Resulting concentrations may severely browse and damage tree seedlings (Crouch 1969). The economically valuable species, douglas fir (Pseudotsuga menziesii), ponderosa pine (Pinus ponderosa), sugar pine (Pinus lambertiana), and white fir (Abies concolor), are all moderately palatable to deer (Longhurst et al. 1968), and may be browsed to varying degrees depending on availability of more palatable alternative forages. Browsing damage also varies with the season of the year, elevation, and other environmental variables.

Livestock also may damage conifer plantations by browsing and trampling. Water, available forage, and stocking rate are the most important factors affecting the a mount of conifer tree damage (Hill 1917, Cassidy 1937). Light to moderate stocking rates with adequate water supply resulted in negligible damage to artificial and natural regeneration in pine-bunchgrass range in Colorado (Currie 1978). Moderate grazing, with provisions to avoid livestock con-

\footnotetext{
Authors are, respectively, Ecologist, Range Management Staff, Forest Service San Francisco, Calif. 94111 ; and Assistant Professor, Range Ecology, Department of Forestry and Resource Management, University of California, Berkeley 94720

Authors would like to thank Robert Heald, forest manager, Blodgett Forest Research Station, for his advice and cooperation in choosing suitable clearcuts for this study, and his help in supplying manpower and materials to build the experimental exclosures.

Manuscript received September 22, 1981
}

centration, caused negligible damage to pine reproduction in the southern Rocky Mountains (Heerwagen 1954).

Damage to trees from livestock results from faulty management, not the livestock themselves (Potter 1913, Jardine and Anderson 1919, Arvola 1978). Wheeler et al. (1980) found cattle grazing was compatible with survival and growth of indigenous timber species in eastern Oregon. Proper livestock management, and timing of grazing with attention to forage abundance, resulted in negligible tree damage. Reported injury to plantations by livestock in California has been light (Schubert and Adams 1975). Sheep and goats generally cause the most damage by browsing, while cattle cause the most trampling damage.

Brush regeneration also limits successful conifer regeneration. Throughout the Sierra, including the study site, brush competes with tree seedlings for water, nutrients and light. Most foresters believe that tree yields are reduced unless the brush is reduced. Chemical sprays, burning and mechanical methods are most often used in site preparation to reduce brush. Follow up control by use of chemicals is usually the chcapcst and easiest (Schubert and Adams 1975, Arvola 1978). However, tightening of federal regulations and increasing public distrust of herbicide use will probably reduce their use. Brush species vary in resistance to eradication, and most are prolific producers of seed which germinate after fire or other disturbance. Livestock grazing could provide an alternative or additional method for brush control. Wheeler et al. (1980) suggest big game also play a significant role in brush reduction on young mixed conifer clearcuts in eastern Oregon.

\section{Methods}

Study began at Blodgett Forest Research Station, near Georgetown, Calif., to look at the effects of cattle and deer grazing on young middle elevation mixed conifer plantations as part of a long term study of the interrelationships between forage and timber production (Kosco and Bartolome 1978, 1982. The specific questions addressed included:

1. Do cattle and/or deer significantly reduce brush cover on plantations?

2. How much do cattle and/or deer damage tree seedlings by browsing or trampling?

3. Do trees, in the grazed treatments, survive better, grow taller, and eventually produce more wood?

We have studied two clearcuts on Blodgett Forest to answer these questions. Methods differ on the two clearcuts and are described separately below.

Clearcut 641E was harvested during the summer of 1977 and planted with 1-0 ponderosa pine, sugar pine, white fir and douglas fir in April 1978. The planted trees were considered by the Forest manager to be in poor physiological condition, yet they were the only seedlings available. The clearcut occupies 2.8 essentially level hectares. The site was prepared for planting using a brush rake to pile accumulated slash. The piles were then burned during the fall of 1977.

Timing of this study and the site preparation coincided so that the exclosures could be built prior to livestock grazing. Three 
treatments were tested: no grazing, grazing by deer alone, and grazing by cattle and deer. Exclosures were laid out on the plot while it was under snow, thus aiding complete randomization. The trees were planted as prearranged by the Forest management in the spring and the exclosures built to a few days later. Brush seedlings were actively growing at this time.

Two $15 \mathrm{~m}$ by $23 \mathrm{~m}$ deerproof exclosures were built with $3 \mathrm{~m}$ cedar posts and $3 \mathrm{~m}$ high woven wire. The three cattleproof plots, built with cedar posts and 3 strand barbwire, measured $31 \mathrm{~m}$ by $23 \mathrm{~m}$, $31 \mathrm{~m}$ by $23 \mathrm{~m}$, and $46 \mathrm{~m}$ by $23 \mathrm{~m}$. A grazed plot of $46 \mathrm{~m}$ by $23 \mathrm{~m}$ was laid out at the same time and marked at the corners with $1.2 \mathrm{~m}$ rebar, making a total of 6 plots.

A grid was placed over the study plots and a random number generator picked coordinates for placement of permanent $10 \mathrm{~m}$ long line transects. The number of transects per plot varied depending on plot size, with 3 transects in the ungrazed plots and 7 transects in each of the grazed plots.

For each treatment, line intercept data for each species were recorded in September 1978, and June and September 1979. At the same time, ten $50-\mathrm{cm}$ square quadrats per transect were equally placed along the line, alternating sides, and density and cover data were recorded. To estimate density, the numbers of seedlings were recorded by species. The number of browsed brush seedlings was also recorded. Cover of brush seedlings was ocularly estimated within each $50 \mathrm{~cm}$ square.

Every tree within the three treatments was measured during all three sampling periods. Species, height, and basal diameter were recorded. In addition, each tree was rated as alive or dead, browsed or unbrowsed, and trampled or not trampled. Tree mortality was high because of poor quality stock. Data from the last sampling period (September 1979) only will be reported. All the trees will have been subjected to 1 or 2 grazing seasons.

Clearcut $481 \mathrm{E}$ is 8.1 hectares, on a relatively steep, east-facing slops, and cut in the summer of 1975 . Site preparation was done with a brush rake in 1976; the accumulated slash piled and burned in the fall of 1966. 1-0 ponderosa pine, sugar pine, douglas fir and 2-0 white fir seedlings were planted in April 1977. Brush seedlings were actively growing at this time. Deer and cattle had free access to the entire clearcut prior to the construction of the exclosures in September 1978 .

Twenty $2.5 \mathrm{~m}$ by $2.5 \mathrm{~m}$ woven-wire exclosures prevented grazing by both cattle and deer. A grid was placed over aerial photos of the study site, and 20 pairs of numbers were randomly generated as coordinates for placement of the exclosures. At the designated coordinate the exclosure was built to include the nearest planted tree seedling. A grazed $2.5 \mathrm{~m}$ by $2.5 \mathrm{~m}$ plot, paired with each exclosure, was placed around the first planted tree seedling to the east of the exclosure.

The exclosures were sampled in September 1979, 1 year after placement. Cover of brush was estimated in 2 ways, ocular estimates of total percent cover were recorded and every plant in the plots was measured, and species, height, width and length were recorded to determine volume and area by species. Each tree was measured, using the methods previously described for $641 \mathrm{E}$.

\section{Effects of Grazing on Brush}

Thirteen brush species appeared on samples from clearcut 641 (Table 1). Greenleaf manzanita was the most frequent shrub occurring on 74 to $86 \%$ of the plots, depending on treatment (Table 2). Mountain misery, rose, mountain whitethorn, and Sierra gooseberry were also common, with the other species listed in Table 1 present in minor amounts. Between 46 and $88 \%$ of the plots containing manzanita, mountain misery, whitethorn, and rose had browsed plants. Mountain whitethorn was browsed most heavily overall; 91 to $100 \%$ of the mountain whitethorn plants on the plots containing this species were browsed. Manzanita, mountain misery, and rose were also heavily browsed with some variation depending on treatment (Table 2).

Percent cover estimates indicate a significant reduction in total
Table 1. Species composition on clearcut $641 \mathrm{E}$ which was cut in July, 1977, planted in April, 1978, with ponderosa pine, sugar pine, white fir, and douglas fir and sampled in September, 1979; and clearcut 481E, which was cut in July, 1975, planted in April, 1977, with the same 4 tree species, and sampled in September 1979.

\begin{tabular}{|c|c|c|}
\hline \multirow[b]{2}{*}{ Species } & \multicolumn{2}{|c|}{ Treatment } \\
\hline & $641 \mathrm{E}$ & $481 \mathrm{E}$ \\
\hline \multicolumn{3}{|l|}{ Arctostaphylos patula } \\
\hline $\begin{array}{l}\text { Greenleaf manzanita } \\
\text { Arctostaphylos viscida }\end{array}$ & $\mathbf{x}$ & $\mathbf{x}$ \\
\hline Whiteleaf manzanita & & $\mathbf{x}$ \\
\hline \multicolumn{3}{|l|}{ Bromus marginatus } \\
\hline Mountain brome & & $\mathbf{x}$ \\
\hline \multicolumn{3}{|l|}{ Ceanothus cordulatus } \\
\hline Mountain whitethorn & $\mathbf{x}$ & $\mathbf{x}$ \\
\hline \multicolumn{3}{|l|}{ Ceanothus integerrimus } \\
\hline Deerbrush & $\mathbf{x}$ & $\mathbf{x}$ \\
\hline \multicolumn{3}{|l|}{ Chamaebatia foliolosa } \\
\hline Mountain misery & $\mathbf{x}$ & $\mathbf{x}$ \\
\hline \multicolumn{3}{|l|}{ Cirsium lanceolatum } \\
\hline Bull thistle & $\mathbf{x}$ & $\mathbf{x}$ \\
\hline \multicolumn{2}{|l|}{ Iris harwegii } & $\mathbf{x}$ \\
\hline Iris & & $x$ \\
\hline \multicolumn{3}{|l|}{ Juncus sp. } \\
\hline Rush & & $\mathbf{x}$ \\
\hline \multicolumn{3}{|l|}{ Prunus emarginata } \\
\hline Bitter cherry & $\mathbf{x}$ & \\
\hline \multicolumn{3}{|l|}{ Quercus kelloggii } \\
\hline Black oak & $x$ & $\mathbf{x}$ \\
\hline \multicolumn{3}{|l|}{ Ribes roezli } \\
\hline Sierra gooseberry & $\mathbf{x}$ & $\mathbf{x}$ \\
\hline \multicolumn{3}{|l|}{ Rosa pinetorum } \\
\hline Rose & $\mathbf{x}$ & $\mathbf{x}$ \\
\hline \multicolumn{3}{|l|}{ Stipa lettermani } \\
\hline Letterman needlegrass & $\mathbf{x}$ & \\
\hline \multicolumn{3}{|l|}{ Symphoriocarpos acutus } \\
\hline Snowberry & $\mathbf{x}$ & $x$ \\
\hline \multicolumn{3}{|l|}{ Vaccinium parvifolium } \\
\hline $\begin{array}{c}\text { Red huckleberry } \\
\text { Verbascum Thapsus L. }\end{array}$ & $\mathbf{x}$ & \\
\hline Common mullein & & $\mathbf{x}$ \\
\hline
\end{tabular}

brush cover in both grazed treatments with an even further reduction in the treatment grazed by cattle and deer (Fig. 1). Significant reductions in mean cover on the grazed treatments show up by September 1979, two grazing seasons after the exclosures were built, although as the plants grow, overall brush cover increases. Density data analyses show no change in mean density of species over time. Shrubs establish in the first year after disturbance.

Eighteen species comprised the sample flora in the treatment plots on clearcut $481 \mathrm{E}$ (Table 1). Deerbrush, squaw carpet, brome grass, gooseberries, manzanita, mountain misery, and thistles are all more common on the ungrazed than the grazed plots, although all of these species are also present on the grazed plots. Deerbrush was the only species with significantly less cover in the grazed treatment than the ungrazed.

Results from analysis of variance indicate significantly less cover on the grazed plots (Fig. 1). Cover on ungrazed plots averaged $39 \%$, while grazed plot cover averaged $14 \%$.

\section{Effects of Grazing on Conifer Seedlings}

In September 1979, all 420 trees from the treatments on clearcut $641 \mathrm{E}$ were sampled. Every tree had been subjected to 1 or 2 grazing seasons. Exclosure integrity was maintained throughout the experiment. Fecal groups and tracks indicated that deer actively used the cattle-proof exclosure at the same intensity as the adjacent unfenced plot. The Forest manager indicated that all trees on the clearcut were of relatively poor stock and a third replanting would be done in April 1980. 
Table 2. Frequency of species occurrence and browsing by species and treatment on clearcut $641 \mathrm{E}$. The average \% browsing on those plots where browsing occurred is also given. Clearcut 641E was cut during July, 1977; planted in April, 1978; and sampled in September, 1979. Sample size, $\mathrm{N}=70$, for each treatment. All other species listed in Table 1 occurred on 2 or fewer of the sample plots.

\begin{tabular}{|c|c|c|c|}
\hline Species and treatment & $\begin{array}{l}\text { \#of plots the species } \\
\text { occurred out of } 70\end{array}$ & $\begin{array}{c}\# \text { of plots } \\
\text { with browsing }\end{array}$ & $\begin{array}{l}\text { Average } \% \text { browsing } \\
\text { on plots with browsing }\end{array}$ \\
\hline $\begin{array}{l}\text { Arctostaphylos patula } \\
\text { Grazed by deer } \\
\text { Grazed by cattle \& deer }\end{array}$ & $\begin{array}{l}52 \\
60\end{array}$ & $\begin{array}{l}40 \\
44\end{array}$ & $\begin{array}{l}64 \% \\
56 \%\end{array}$ \\
\hline $\begin{array}{l}\text { Chamaebatia foliolosa } \\
\text { Grazed by deer } \\
\text { Grazed by cattle \& deer }\end{array}$ & $\begin{array}{r}4 \\
12\end{array}$ & $\begin{array}{l}3 \\
9\end{array}$ & $\begin{array}{l}78 \% \\
69 \%\end{array}$ \\
\hline $\begin{array}{l}\text { Ceanothus cordulatus } \\
\text { Grazed by deer } \\
\text { Grazed by cattle \& deer }\end{array}$ & $\begin{array}{l}20 \\
11\end{array}$ & $\begin{array}{r}12 \\
9\end{array}$ & $\begin{array}{r}100 \% \\
91 \%\end{array}$ \\
\hline $\begin{array}{l}\text { Rosa pinetorum } \\
\text { Grazed by deer } \\
\text { Grazed by cattle \& deer }\end{array}$ & $\begin{array}{l}13 \\
33\end{array}$ & $\begin{array}{r}6 \\
29\end{array}$ & $\begin{array}{l}56 \% \\
83 \%\end{array}$ \\
\hline
\end{tabular}

Results show browsed trees on both the grazed treatments. White fir was browsed the most heavily; $45 \%$ were browsed in the treatment grazed by deer alone and $53 \%$ were browsed in the treatment grazed by cattle and deer. Table 3 gives number of trees per treatment by species, and the number and percent browsed. Although trees are browsed, numbers browsed did not differ significantly between treatments. Cattle and deer combined did not

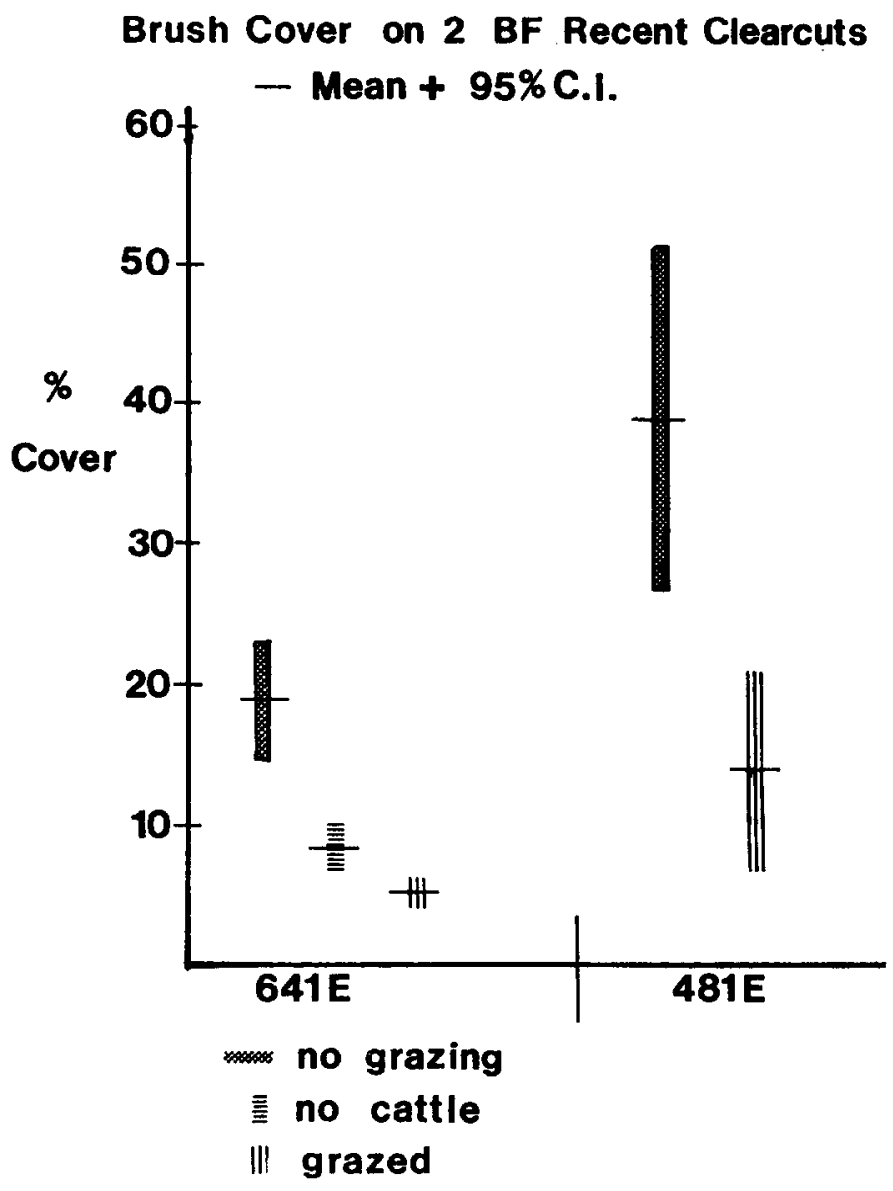

Fig. 1. Estimates of \% brush cover indicate a significant reduction in brush in grazed treatments on both clearcuts on Blodgett Forest (BF). Furthermore brush cover is further reduced on the treatment with grazing by cattle and deer. There is more total brush cover on $481 \mathrm{E}$ because it is 4 years post harvest versus 2 years post harvest in 641 . Grazing animals appear to be a useful tool to reduce brush cover on regenerating mixed conifer clearcuts. browse significantly higher numbers of trees than deer alone.

Minimal trampling damage occurred to conifer tree seedlings on the study plots. Four trees suffered trampling damage, one in the treatment grazed by deer, and 3 in the plot grazed by cattle and deer out of a total of 420 trees.

Frequency data show that douglas fir had the highest mortality rates and white fir and ponderosa pine the lowest. Most of the trees died in the ungrazed treatment, although the generally poor planting stock precludes more definite conclusions about the long-term relationship between conifer seedlings and brush density.

No significant difference in average tree height between species or treatment had appeared on this clearcut 2 years after planting. White fir tended to be the shortest, but no general trend related to treatment was discovered. No significant difference existed in tree seedling basal diameters between species or treatments. The only statistically significant result was that white fir on the treatment grazed by deer is significantly smaller in basal diameter and shorter in height than any other tree species on the same treatment. This is probably a result of pressure on white fir, though this result does not show up in the cattle and deer treatment. Trends in height, basal diameter or survival with regard to treatment will only appear with continued monitoring.

In contrast to clearcut $641 \mathrm{E}$, trees were planted on clearcut $481 \mathrm{E}$ only once in April 1977. Exclosures to prevent deer and cattle use were built in September 1978, after 2 seasons.

Only one (a douglas fir) of the 61 monitored trees was browsed and trampled. None of the trees on the sampled plots died. After 1 year without grazing, no significant difference was detected in tree height or basal diameter between treatments. Continued monitoring should show differences as the trees and brush mature.

\section{Conclusions}

Grazing reduced brush cover on both clearcuts without harming most conifer seedlings. Livestock significantly reduced brush cover with a further reduction observed when cattle and deer were combined. The ultimate effect of this brush reduction on trees will be

Table 3. Number and percent of trees browsed by species and treatment on Clearcut 641E. No significant difference exists in total numbers of trees browsed in the grazed treatments. ANOVA $(\alpha=0.05)$.

\begin{tabular}{lcrrrr}
\hline \hline Tree species & No grazing & \multicolumn{2}{c}{$\begin{array}{c}\text { Grazed by } \\
\text { deer }\end{array}$} & $\begin{array}{c}\text { Grazed by } \\
\text { cattle and deer }\end{array}$ \\
\hline White fir & 0 & $23 / 50$ & $46 \%$ & $21 / 40$ & $53 \%$ \\
Douglas fir & 0 & $1 / 80$ & $1 \%$ & $3 / 65$ & $5 \%$ \\
Ponderosa pine & 0 & $3 / 34$ & $9 \%$ & $0 / 16$ & $0 \%$ \\
Sugar pine & 0 & $0 / 16$ & $0 \%$ & $1 / 5$ & $20 \%$ \\
$\quad$ & 0 & $27 / 180$ & $15 \%$ & $25 / 126$ & $20 \%$ \\
\hline
\end{tabular}


realized 60 years from now when timber is harvested, but has not yet been demonstrated.

Meanwhile, livestock and deer utilize species of brush seedlings as forage which are not preferred as mature plants. When livestock are allowed free access to the clearcuts they utilize brush species frequently as they move about the study area. During the short summer grazing season, forage sources, herbaceous and palatable browse, are not limiting to livestock. The availability of other forage supplies and avoidance of animal concentration on the clearcuts minimizes tree damage, while still allowing significant utilization of browse species.

Some trees were browsed, few were trampled. Deer browsed most of the trees as determined from observations of tracks, timing of browse damage and browsing in cattle-proof exclosures. Only an insignificant increase in tree browsing and damage resulted from the addition of cattle to ongoing deer browsing. Animals browsed white fir preferentially. The other planted species suffered negligible browsing. Neither brush reduction nor browsing have yet shown a significant effect on tree vigor or growth.

Livestock grazing shows potential not only as a compatible use of mixed conifer forests, a use which when properly controlled conflicts minimally with timber production, but as an aid to brush control on new clearcuts. Livestock most effectively reduce brush in the first few years after clearing. Where animals have free movement, which is essential to avoidance of concentrations and potential damage to tree seedlings, palatable browse species, such as deerbrush, must make up a large portion of brush cover to continue to attract animals. Grazing alone will not usually control brush significantly enough to satisfy the forester. However, we suggest that as other options become more costly, a virtually free vegetation management technique like grazing should be more fully utilized.

\section{Literature Cited}

Arvola, T.F. 1978. California Forestry Handbook. State of California, Dept. of Forestry.

Bartolome, J.W., and B.H. Kosco. 1982. Estimating browse production by deerbrush. J. Range. (In press).

Cassidy, H.0. 1937. How cattle use cut-over ponderosa pine-bunchgrass ranges with minimum injury to reproduction. USDA, Forest Serv. Res. Note 15, S.W. Forest and Range Exp. Sta. Tucson.

Crouch, G.L. 1969. Wildlife and reforestation in the Pacific Northwest. Symp. Proc. USDA Forest Serv., Oregon State Univ.

Currie, P.O., C.B. Edminster, F. William Knott. 1978. Effects of cáttle grazing on ponderosa pine regeneration in central Colorado. USDA, Forest Serv. Res. Paper RM-20l.

Heerwagen, A. 1954. The effect of use upon ponderosa pine reproduction in the Rocky Mountain area. Soc. Amer. Foresters (Milwaukee, Wis.) Proc. p. 206-207.

Hill, R.R. 1917. Effects of grazing upon western yellow pine reproduction in the national forests of Arizona and New Mexico. USDA Bull. \#580.

Jardine, J.T., and M. Anderson. 1919. Range Management on the National Forests. USDA Bull. \#790.

Kosco, B.H., and J.W. Bartolome. 1978. Grazing mixed conifer forests. California Agr. 32:5-7.

Longhurst, W.M., H.K. Oh, M.B. Jones, and R.E. Kepner. 1968. A basis for the palatability of deer forage plants. 33rd N. Amer. Wildlife and Nat. Res. Conf., Houston, Texas. March 11.

Potter, A.F. 1913. Administration of grazing in National Forests. Address before the 16th annual convention of the American National Livestock Association. Phoenix, Ariz., January 15th.

Roy, D.F. 1960. Deer browsing and Douglas-fir seedling growing in northwestern California. J. Forest. 58:518-522.

Schubert, G.H., and R.S. Adams. 1975. Reforestation Practices for Conifers in California. State of California, Division of Forestry.

Wheeler, W.P., W.C. Krueger, and M. Vavra. 1980. The effects of grazing on survival and growth of trees planted in a Northeastern Oregon clearcut. Spec. Rep. \#586. Agr. Exp. Sta., Oregon State Univ., corvallis. p. 28-31. 